\title{
What can the philosophy of science contribute to the ethics of science and technology?
}

Márcio Rojas da Cruz ${ }^{1}$, Gabriele Cornelli ${ }^{2}$

\begin{abstract}
Born to enable its creators to fulfill their needs, scientific technique has always played a significant role in human civilization. This is the context in which we glimpse the advent of modern technoscience, which has significantly contributed to the increment of human control over nature. This study aims to analyze, under the focus of bioethics, reflections on the philosophy of science as they relate to the neutrality of science and converge with epistemic rationality, as well as to relate those reflections to the process of making decisions in the administration of technoscience. The study has raised doubts about the capacity of technoscientific knowledge to legitimize and justify the decisions within the ambit of the national science and technology systems, thus signaling the need for promoting a link between technoscientific self-regulation and bioethic hetero-regulation.
\end{abstract}

Keywords: Bioethics. Knowledge. Science. Science, technology and society.

\section{Resumo}

O que pode a filosofia da ciência contribuir para a ética da ciência e tecnologia?

Nascida para permitir que seus criadores possam atender suas próprias necessidades, a técnica científica sempre desempenhou papel significativo na civilização humana. Este é o contexto em que podemos vislumbrar o advento da tecnociência moderna, que tem contribuído significativamente para o incremento do controle humano sobre a natureza. Este estudo tem por objetivo analisar, sob o enfoque da bioética, reflexões sobre como a filosofia da ciência entende a neutralidade da ciência e sua convergência com a racionalidade epistêmica, bem como relacionar essas reflexões ao processo de tomada de decisões na administração da tecnociência. $O$ estudo levantou dúvidas sobre a capacidade do conhecimento tecnocientífico para legitimar e justificar as decisões no âmbito dos sistemas de ciência e tecnologia nacionais, sinalizando assim a necessidade de promover ligação entre a auto-regulação tecnocientífico e hetero-regulação bioética.

Palavras-chave: Bioética. Conhecimento. Ciência. Ciência, tecnologia e sociedade.

\section{Resumen}

\section{¿En qué puede contribuir la filosofía de la ciencia a la ética de la ciencia y la tecnología?}

Nacida para permitir a sus creadores satisfacer sus necesidades, la técnica científica siempre ha desempeñado un papel importante en la civilización humana. Este es el contexto en el que se vislumbra el advenimiento de la tecnociencia moderna, la cual ha contribuido significativamente al incremento del control humano sobre la naturaleza. Este estudio tiene como objetivo analizar, bajo el enfoque de la bioética, reflexiones acerca de cómo la filosofía de la ciencia entiende a la neutralidad de la ciencia y a su convergencia con la racionalidad epistémica, así como relacionar estas reflexiones con el proceso de toma de decisiones en la administración de la tecnociencia. El estudio ha puesto en duda la capacidad del conocimiento tecnocientífico para legitimar y justificar las decisiones en el ámbito de los sistemas nacionales de ciencia y tecnología, señalando así la necesidad de promover un vínculo entre la autorregulación tecnocientífica y la hetero-regulación bioética. Palabras-clave: Bioética. Conocimiento. Ciencia. Ciencia, tecnología y sociedad.

1. Pós-doutorando mrojas@mcti.gov.br 2.PhD cornelli@unb.br - Universidade de Brasília (UnB), Brasília/DF, Brasil.

Correspondência

Gabriele Cornelli - Programa de Pós-Graduação em Bioética da Universidade de Brasília. Campus Universitário Darcy Ribeiro, Faculdade de Ciências da Saúde - Caixa Postal 04451 - CEP 70904-970. Brasília/DF, Brasil.

Declaram não haver conflitos de interesse. 
On a certain occasion Popper registered his agreement with Russell regarding epistemology's practical consequences for science itself, as well as for ethics and politics. Popper and Russell agreed to draw both epistemological relativism and epistemological pragmatism closer to totalitarian and authoritarian ideas ${ }^{1}$. Based on Popper's and Russell's view of the proximity between epistemological relativism/epistemological pragmatism and totalitarian/authoritarian ideas, we propose to approach the philosophy of science in order to elucidate the practical consequences that could be drawn from its contributions to epistemology.

We have been following the remarkable scientific advances of recent years, particularly those concerning the biotechnoscientific paradigm. Made possible by Darwin's theory of evolution and Mendel's genetic theory, and brought into being by Watson and Crick's elucidation of the structure of DNA and by the subsequent development of genetic engineering protocols (with restriction enzymes, DNA ligases, DNA polymerases, chain reactions, etc), the biotechnoscientific paradigm represents our technical competence for transforming and reprogramming the natural environment, other living beings and oneself according to one's plans and wishes $^{2}$, allowing us in theory to become, in a way, immune to the mechanisms of natural selection and the other significant factors influencing the process of evolution of living species ${ }^{3}$.

It is noteworthy that this sometimes surprising potential had already been pointed out by Popper himself when, reflecting upon scientific progress in general, he realized that from an evolutional and biological point of view science is an instrument used by the human species to adapt to the environment, to invade new environmental niches and even to create new environmental niches ${ }^{4}$.

In this context we are confronted by the following issue: scientific undertaking grants us an exclusively technical a priori competence, but not necessarily an ethical competence. A significant proportion of products and processes which adhere strictly to the biotechnoscientific paradigm raise ethical dilemmas which cannot be resolved in even a minimally satisfactory way without exhaustive studies and discussions. We cannot, therefore, evade our responsibility to evaluate the ethical and moral consequences of modern scientific actions.

Scientific and technological progress, which together offer the prospect of definitively solving the most diverse problems (health, social, environmental, etc.), have also allowed modern society the development of an articulated process of mythification of the practice of science itself.

For Feyerabend, a myth is a system of thought, imposed and preserved through indoctrination, which offers explanations about reality according to facts which correspond to elements of so-called common sense, and also possesses the characteristic of infallibility ${ }^{5}$. Scientific theory, on the other hand, is a system of thought with counterintuitive and counter-inductive general explanations which are arrived at by the most brilliant thinkers. However, since scientific theory is essentially a human achievement, it has the characteristic of fallibility ${ }^{6-7}$. The lack of clarity between the defining properties and the consequent limitations of a scientific theory, confusing itself with the conception of a myth, ends up allowing the possibility to perceive science as a myth, creating the risk that possible mistakes and negative effects in modern scientific activity might be neglected.

It is relevant to point out that the prevailing conception of scientific knowledge, which is exclusively focused on methodological and epistemic justification - the mythified image of scientific endeavors - is liable to create an asymmetry between science on one side and moral and political aspects on the other, with the corollary of creating a hierarchy in which epistemic values take priority positions to the detriment of political and ethical values. In this context the issue of "epistemic authoritarianism" arises, characterized by the ideology that scientific knowledge is not only a necessary condition but is also sufficient to justify and legitimate political decisions ${ }^{8}$.

This study will therefore aim to relate the neutrality of science and convergence on epistemic rationality to ethics in science and technology. Specifically, we will reflect upon the contribution of Karl R. Popper, Thomas S. Kuhn and Paul K. Feyerabend's philosophy of science to the fundamental assumptions of scientific activity in its interface with bioethics.

It's noteworthy that the discussions particularly related to scientific neutrality and the convergence on epistemic rationality are fundamental to the reflection concerning the bioethical management of technoscientific systems. This centrality is a consequence of the fact that scientific neutrality is the main argument in defense of total scientific autonomy, prescinding any type of regulation other than autoregulation, bestowing a sort of "immunity" or "privilege" on the exercise of scientific activity regarding considerations of a moral order. 
As for the convergence on epistemic rationality, on the other hand, the centrality emerges because it is the main argument in defense of the sufficiency of opinions and recommendations based on scientific knowledge on matters that aim to settle contentions of various orders, endowing scientific speech with a sort of "superiority" that would make its "exclusivity" acceptable.

\section{Popperian propositions}

I disbelieve in specialization and in experts. By paying too much respect to the specialist, we are destroying the commonwealth of learning, the trationalist tradition, and science itself ${ }^{9}$.

Let us first elucidate in the most precise way possible the practical consequences, within the ambit of bioethics, of Popper's contributions to the philosophy of science. The first point regards ethical principles as the search for truth and the ideas of intellectual honesty and fallibility, such principles forming part of the very basis of science ${ }^{10}$. Without meaning to belittle these principles, it is clear that they are far from sufficient in order for the scientist to be clearly and transparently provided with advice from physics about whether to build "a plow, an airplane or an atomic bomb" ${ }^{11}$. Therefore, acknowledging that the scientist is influenced by a number of factors - not only from their professional sphere but also from their personal sphere - in proposing "new professional ethics", Popper states that the first principle should be an acknowledgment that there is no authority, since our conjectural and objective knowledge exceeds, more and more, what one person can master ${ }^{12}$.

The second point addresses the "problem of induction", where universal empirical statements are logically prevented from being declared true, independently of the quantity and quality of confirmatory evidence. The expression "scientific truth" completely loses the meaning of its existence, since the successes from the "trial, error and successes method" do not guarantee the timelessness of a certain scientific theory. One cannot abstract the time factor from any element of scientific knowledge, however solid it might initially appear, even if it remains irrefutable for decades or even for centuries.

The case of Newtonian physics, still applied today in numerous situations even though it has been overtaken by Einsteinian physics, is a good example of how a high degree of empirical solidity is not enough for a scientific theory to be declared true. The lay conception that scientific theories are hypotheses that have been confirmed by experimentation strictly adjusted to a virtually infallible methodology is to be replaced by a medley of hypotheses and scientific theories. What we accept today as scientific theories are actually conjectures, hypotheses, assumptions and possibilities which until now have remained worthy of consideration in the scientific sphere - but there is no guarantee such worthiness will endure in the future.

The next point to emerge concerns the origin of scientific theories and their impact on scientific progress. According to Popper, pure and impartial sensory perceptions are not in the basis of scientific theories, so the "bucket theory of the mind" is discarded. The data must not be worshipped on the altar of science because they are not the basis nor the guarantee for the theories: they are no more reliable than any of our theories or 'biases', but much less, if anything ${ }^{13}$. This role of basis to the science is performed by problems the scientific community regards as important and theories the scientific community not only formulates in speculative fashion but also sometimes defends in a dogmatic way, ignoring occasional empirical refutations, as indicated by the "spotlight theory".

Naturally, at each one of these stages - the prioritization of problems to be solved, the formulation of scientific theories to be tested, the dogmatic defense of certain theories - there are countless opportunities for idiosyncrasies to influence the scientist's thoughts and actions. Popper himself declares that nothing is ever accomplished without a dose of passion ${ }^{14}$, acknowledging the partiality and subjectivity of men of science who allow themselves to be guided by fears, necessities and preferences. By affirming that the objectivity and rationality of all scientists hinder the scientific process, precedents are created so that the very idea of scientific neutrality, and consequently scientific autonomy, is called into question.

It is noteworthy that even though science could surely be considered neutral and autonomous, it would be inconsistent to automatically attach such adjectives to individual scientists or organized research groups. Their activities should be subjected to thorough examinations of an ethical nature in order to minimize the risk of abuses committed in the name of science. In this sense the epistemologist argues that scientific rationality and objectivity do not depend on the personal rationality and objectivity of each of the scientists working in a certain 
field. Instead they emerge from the social aspect of the scientific method, more specifically through the tradition of critical review which drives scientists towards leaning through the detection of errors.

Would this argument be enough for science to be considered rational and objective? Undoubtedly the intersubjectivity of scientific method is able to make a positive contribution to the rationality and objectivity of science. However, such a contribution is not absolute, not being able to exhaust all possibilities for eliminating irrational and subjective influences.

Such a scenario would not only compromise the rationality and objectivity of science but also compromise the convergent conception of scientific rationality and objectivity. As Popper realized, the emergent conflict in the scientific dynamic between the feature of science developing in a path-dependent way and the final convergence tendency might only be partially resolved by looking into the matter of rational critical review as responsible for enabling the approach to one truth, having also overcome the restrictions imposed by the debate regarding incommensurability, or by the "myth of the context".

Considering that the scientist is involved in an undertaking which minds more the doxa than the episteme - making it impossible to guarantee the veracity of the knowledge regarded as the reference point - when their considerations are being applied, especially when such considerations conflict with recommendations from other sections of society, it should not be the case that greater weight is attached, a priori, to the scientist's feedback than to that of the non-scientist. At this point it should be made clear that the "principle of objectivity of basic statements", valid to all sciences, does not necessarily imply the denial or refutation of statements which are not intersubjectively testable. Such statements must be ignored by science, in the sense that science is intrinsically limited to its ability of evaluation outside the empirical sphere ${ }^{15}$. Therefore, certain lines of thought in psychology or theology, for example, are not necessarily false just because they have not been submitted to the mechanisms of intersubjective tests.

\section{Kuhnian propositions}

Science is not the only activity the practitioners of which can be grouped into communities, but it is the only one in which each community is its own exclusive audience and judge ${ }^{16}$.
As was done with Popper, we will now analyze Kuhn's contributions, starting with those currently considered to be under the ambit of bioethics and extrapolating them from their initial context so they can interact with contemporary bioethical concerns.

Let us begin, then, with the existing relation between the facts as they are laid out by the world and the beliefs inhabiting our cognition concerning this world. According to Kuhn, the incommensurability which is perceived when two paradigms separated from each other in their timeline are analyzed attests to the nonexistence of a neutral empirical language system or concept system ${ }^{17}$. In this situation we come across a significant limitation of our abilities to analyze a data set.

In the universe of all possible and imaginable paradigms, we are consequently restricted by the incommensurability to only access the set of paradigms our scientific lexicon allows us. We are rational beings gifted with a "vision through a paradigm", as if something that could be considered a kind of paradigm was an indispensable requisite to perception, as if what we see were in a way a product of our previous visual-conceptual experience ${ }^{18}$.

On this topic there is still room for a detail that makes the fact-belief relationship even more complex: the individual nature of the vision through a paradigm. The stimulus-sensation correlation, due to the neural process that happens when a stimulus to the perception of sensation is received, is neither absolutely linear nor independent from the previous education of each researcher. It is perfectly conceivable that two scientists who perform an identical experiment see different things, or see the same thing differently, receiving different data and processing different stimuli ${ }^{19}$. It is interesting to note that this reflection already appeared in Kuhn's first texts, in the 1940s, when it was concluded that the conditions of cause and effect actually result from constructions of deterministic mathematical formulas responsible for the causal connection of events ${ }^{20,21}$.

Add to that a direct implication of incommensurability, which equally impacts on the belief that science, throughout its progress, is moving ever closer to the truth as realized by tradition in the philosophy of science, meaning something which corresponds to what is real, to the outside world, independently from the mind. When the designation of "truth" is applied to a theory, in an internal and restricted way, there is no reason for unrest or discomfort. In fact, as a general rule, practically all members of a scientific community will agree on the 
consequences of a theory. Conclusions that remain unshaken throughout experiments will be held to be correct, the ones that don't fit will be held as wrong, and there may still be a third group of consequences which would encompass those conclusions which haven't been properly tested.

Nonetheless, when substituting the comparison among consequences of the same theory for the comparison among distinct theories called to offer an organized vision of the same group of natural phenomena, the use of the "truth" label must be more parsimonious. Previous theories are no longer a consensus for being considered false in the light of a more recent theory, even though they were once held to be true ${ }^{22}$. Kuhn uses the expression transiency of treasured scientific beliefs to call attention to the fact that there were no means to prove that a certain paradigm is final and that the progress of science takes place with recurrent destructions and substitutions of concepts ${ }^{23-25}$. For these situations, the discourse on truth takes on an implicit tone of temporariness, of provisionality. Seen this way, the incommensurability not only compromises the assumption that the process of choosing among theories takes place rationally, but also compromises the assumption that changes in scientific theories occur in a progressive way ${ }^{26}$.

Besides the matter of incommensurability one must also consider what the literature refers to as a "negotiation process" through which the dominant consensus is established. In a negotiation there is a choice between scientific facts which are relevant to the extraction of conclusions (factual aspect), as well as a choice between the conclusions themselves (interpretative aspect). Considering that both factual and interpretative aspects of the negotiation process are simultaneous, one can naturally identify a circularity: at the same time that the facts influence the conclusions drawn from them, so too do the conclusions influence the description of the facts ${ }^{27}$.

And here again there is a detail that makes the matter more complex: the influence of mere biographical matters in the negotiation process. The divergences among the conclusions of participants in the negotiation can ultimately be attributed to the differences in individual history, research fields and personal interest: Interests, politics, power and authority perform, without a doubt, a significant role in scientific life and its development ${ }^{28}$.

In spite of the fact that at the intra-paradigm level the methodological rules are extensively shared by the members of a scientific community - a result of the dogmatic way of knowledge transmission to learning scientists - when considering inter-paradigm matters, methodological rules turn into epistemic values ${ }^{29}$. Kuhn does not actually completely compromise the role performed by objectivity in science, but only a particular philosophical image of scientific objectivity, through the relocation of the criterion of objectivity and truth in the context of scientific practice ${ }^{30}$. Consequently, the use of such epistemic values in certain contexts may happen in a significantly divergent way, this divergence being the result of the different importance given to values which are sometimes mutually conflicting.

Consistency, empirical adequacy, simplicity, explanatory power, predictive power, inter alia, are criteria which might be valued differently by different scientists, for there are no a priori hierarchies. This means that parallel to the consideration of epistemic values there is also the consideration of non-epistemic values through the influence of idiosyncratic factors dependent upon individual biographies and particular personality traits. The corollary is that every individual choice between competing theories depends on a mixture of objective and subjective factors, or on shared and

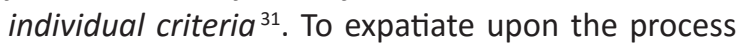
through which a dominant paradigm is achieved, let us make clear that:

no paradigm which has emerged from possibilities worthy of consideration by the scientific community has been able to offer a plausible solution to the absolute totality of the problems the world presents; and

competing paradigms do not have identical limitations when it comes to offering plausible solutions to the problems the world presents.

Therefore the negotiation process might be considered as the prioritization of problems that should not remain among those lacking plausible solutions. Naturally, it is in this situation that the "totally external to science criteria" will gain crucial importance to the revolutionary quality in debates among paradigms ${ }^{32}$.

\section{Feyerabendian propositions}

Western civilization as a whole now values efficiency to an extent that occasionally makes ethical objections seem 'naïve' and 'unscientific'. There are many similarities between this civilization and the 'spirit of Auschwitz'33. 
A well-known critic of the practice of acquiring knowledge through scientific activity, Feyerabend, through his reflections on the philosophy of science, presents us with a new thinking regarding the modalities of political-administrative practices in the scientific ambit. Let us therefore move on to his impact on bioethical debates, looking at his epistemology regarding fundamental assumptions of science and extracting consequences for the ethical management of the science and technology system.

The prominence achieved by Feyerabend probably derives from his defense of the thesis that science does not currently possess the quality of uniformity (and nor did it in the past). His studies revealed that science does not have just one vision of the world but instead exhibits a variety of tendencies and research philosophies. In one corner, there would be the "Aristotelian line", represented by scientists concerned with avoiding exaggerated speculations and restricting themselves to the facts, with experimental designs unequivocally indicating one hypothesis among conflicting ones. In the opposite corner, there would be the "Platonic line", whose representatives feel encouraged to speculate and propose theories that interact with the facts in an indirect and highly complex way ${ }^{34}$. However, in spite of the immeasurable diversity of world views in science, and a similar diversity of metaphysical bases, a significant portion of these views are empirically acceptable ${ }^{35}$. In fact, his historical research towards a characterization of the scientific method made him ubiquitously known as the proponent of the "anything goes" principle.

Feyerabend thus comes to defend the idea that if scientists' activities were strictly oriented by methodologies in accordance with the ideas of objectivity - which emerges when a nation, a tribe or a civilization identifies its way of life with the laws of the universe (physical or moral), and which becomes apparent when cultures with different objective views come into confrontation ${ }^{36}$ - and reason - which has its origins in the assumption that there are standards for knowledge and standards for actions that are universally valid ${ }^{37}$ - the knowledge we have today regarding nature simply would not have been achieved. Paradigmatic events in the history of science, admired not only by scientists but also philosophers and laymen (for example Galileo Galilei's contributions), should not be seen as having been driven by objectivity or reason.

In this sense, the first step towards the consequences of the reflection in the philosophy of science regarding the ethics in science and technology is to disassociate scientific endeavor from the image of a neutral initiative from a moral standpoint. The fact that science is devoid of rational and objective methodology, and guided by evidence which is subject to historical and physiological influences ${ }^{38}$, invalidates the belief that only epistemic values (such as consistency, empirical adequacy, simplicity, explanatory power and predictive power) influence the final result of the process of generating knowledge.

Another equally important step is to come to see scientific endeavor as an instrument (more important in some areas, less in others) which guides and/or enables the unraveling of the most diverse practical disorders, instead of approaching an ultimate truth. The incommensurability thesis questions the rationality, which supposedly guides the process of choosing between divergent scientific theories, and also questions the supposed progressive feature when it comes to succession between scientific theories ${ }^{39}$. Furthermore, scientific results, being predictable only when properly inserted in an experimental arrangement, provide to knowledge a feature, which is fundamentally contextual and specific to certain situations ${ }^{40}$.

Given that science is dependent upon the environment in which it is conceived and developed, by linguistic influences ${ }^{41}$; devoid of standard auto-correction mechanisms ${ }^{42}$ and standardization of progress ${ }^{43}$; and equipped with mutually exclusive theories, which coexist having the same empirical basis or demonstrating incommensurability characteristics ${ }^{44}$, it is not in tune with the convergent conception of epistemic rationality. There is no way that specialists immersed in different cultures although fit to develop, without limitation whatsoever, the ability to know the world, will coincidently arrive at the exact same belief regarding the world by the end of their journeys.

Besides, specialists' abilities do not exempt them from criticism: they do not possess all the knowledge concerning a specific phenomenon but instead only that of a specific field; and indeed usually dedicate themselves to the study of only a limited group of characteristics of that field, in accordance with their own personal interests ${ }^{45}$. Because they are an interested party - wanting a respectable position, a good salary and continued funding for their particular line of scientific investigation - wider society should not be exclusively subject to automatically accept whatever specialists indicate as being the right path to follow. Indeed, the generation of consensus in the scientific environment has much in common with the processes 
that precede the conclusion of political deals, not to mention other factors in the realm of economic and national interests ${ }^{46}$.

Science therefore ceases to have a special status; it is an undertaking marked by successes and failures, consisting of distinct approaches that only sometimes achieve the final result that was expected and fervently desired ${ }^{47}$. The most important point is that science, as Feyerabend had warned, is revealed as being incapable of disregarding what happens outside its borders. In this way, science will come to be seen as one among several traditions for attaining knowledge of reality, which contribute to society moving closer to achieving its aspirations.

So science will not have any special privilege bestowed on it, for nothing entitles a society or even a scientific community to consider itself superior to any other tradition. Every different tradition may then enjoy equal rights of acknowledgement of their values and contributions, as well as corresponding access to those agencies that make political decisions. This new proposed definition of a free society differs from the usual definition, in which a free society is one where its individuals enjoy equal rights to access positions that were previously defined and restricted by a particular tradition, such as Western science and rationalism ${ }^{48}$.

\section{Discussion}

Almost 40 years ago, Jonas alerted us to the fact that we should concern ourselves with investigating the close relation between theory and practice in the way science was being conducted, and essentially in how it should be conducted: We shall then see that not only have the boundaries between theory and practice become blurred, but that the two are now fused in the very heart of science itself, so that the ancient alibi of pure theory and with it the moral immunity it provided no longer hold ${ }^{49}$. This warning of the loss of the alibi which granted science moral immunity refers us to the question about whose task it is to evaluate the morality of the various possibilities of scientific activities.

So far we have learned that scientists do not possess intrinsic authority, seeing that the presuppositions of scientific neutrality and convergency in epistemic rationality have been made contestable by studies in the philosophy of science. It may be timely to note that even if scientific endeavor were to grant its actors/representatives intrinsic authority - that is, if we could imagine even for a moment a hypothetical epistemic scenario in which the presuppositions of scientific neutrality and the convergency in epistemic rationality were undisputed, irrefutable and valid ad eternum - the management of science and technology, or even the government of a society, should still not be exclusively centralized in the hands of scientists, as if they were platonic tutors:

Empiric evidences are important and necessary, never sufficient. When deciding how much to sacrifice to attain a goal, goods or an objective in order to achieve a certain amount of another, we necessarily surpass anything that strictly scientific knowledge may provide 50 .

Beyond the argument about the insufficiency of scientific knowledge - considering intrinsic and extrinsic limitations - there are also other arguments that could be invoked in support of the participation of society in the management of technoscience. A recurrent argument regards the origin of resources. Considering that the financing of scientific research and technological development comes mainly from public funds, which is to say taxes collected from the general population, nothing would be more just than enabling the citizen to participate in the process of decision-making concerning the allocation of resources in technosciences. If the citizen is paying, let them also give their opinion about the benefits that will be sought and also about the harm that occasionally (considering risk analysis) will be done. If there is some kind of "joint sharing" of costs concerning investment, let there also be a joint sharing of possible positive results arising from the research.

Naturally, from the point of view of the democratic management of science and technology, it would be unacceptable to allow social participation only when we were strictly dealing with public investments. Even though the cost of investments is not shared - and even though we are taking into account research projects that are privately financed - the positive or negative impacts of the great majority of technoscientific systems (particularly, biotechnoscientific systems) are invariably felt by more than one social group. Furthermore, what to one group of people might appear to be the positive impact of a particular research activity could actually be negative for another group. For example, the conception of a new Genetically Modified Organism might increase the productivity of a certain crop, boosting a famer's profits, but at the same time contaminate the organic crops of neighboring farmers, thereby causing them financial losses. Let's keep in 
mind all the reflection symbolically represented by Bacon's quote: "ipsa scientia potestas est".

Perhaps the most important argument, however, concerns the potential gains arising from public involvement in the management of technoscience. The consideration upon the desirability of strictly objective evaluations (if indeed they are possible) indicates that the subjectivity might be capable of contributing to the evaluation by plural committees, so as to eventually achieve more satisfactory results.

Although the participation of laymen adds certain financial costs to the decision-making process, scientific knowledge, as relevant as it may be considered, remains instrumental. Its relevance derives from its significant contribution to solving the most diverse problems, but from a moral standpoint it remains an instrument which should be used only in appropriate circumstances. Of equal importance to instrumental knowledge is speculative knowledge, which makes significant contributions to our understanding of the moral scenario, so that social participation will give the decision-making process a real chance of maximizing the desirable benefits and minimizing the undesirable risks.

It is virtually a moral necessity for there to be close cooperation between technoscientists and laymen whose communities the technoscientists wish to study, change or improve. This is not the naive proposition of replacing scientific autonomy with a social heteronomy in science. A vast array of decisions concerning technoscientific activities would remain in the sphere of autoregulation, such as the development of approved projects or the discussions regarding theories and their different degrees of corroboration. However, some of the decisions would take into account the position of not only technoscientists but also of laymen in technoscience - for example as to whether it would be acceptable to submit a community to certain risks (some known, some unknown) so as to possibly achieve a certain benefit.

Moving beyond the previous reflections in the philosophy of science, we get to the point of promoting an inversion of the roles performed by scientific truth and by ethics, at least in specific situations. Reflecting upon Molina and Rowland's research on chlorofluorocarbons (CFCs) for which they received the Nobel Prize in Chemistry in 1995, Olivé reaches the conclusion that scientific knowledge is capable of implying a moral responsibility, which is to say that in certain circumstances, having certain rationally-based beliefs or objective knowledge automatically obliges the scientist to choose between two or more possible courses of action ${ }^{51}$. However, truth as declared by science does not always influence the nature of ethics - in certain cases the situation is exactly the opposite: Ethics, with all its weights and propositions, influences the very nature of truth.

At the same time, moral conflicts often lie at the heart of the most diverse dissensions, instead of being the solution. And the previous consensus regarding ethics in technoscientific initiatives, having been established by the widest possible participation from various sectors of society, would create the most favorable conditions for technoscientific development in harmony with the wishes of a given community.

\section{Final considerations}

The study of the fundamental assumptions of techno-science, as reflected by the philosophy of science, unequivocally reveals the indispensability of social participation in decision-making processes regarding techno-scientific undertakings. When the assumptions about scientific neutrality and the convergence on epistemic rationality - which form the legitimating basis of epistemic authoritarianism - were contested, the inadequacy of scientific knowledge for justifying political decisions was revealed. For the management of the techno-scientific system to be considered bioethical, the involvement of the communities affected by technological developments is indispensable.

This article does not aim to combat science. It would be utterly unrealistic to call for a moratorium on investments in science and technology. The increase in human life expectancy, for example, is sufficient to demonstrate the value of scientific and technological advances. However, one cannot lose sight of the fact that increasingly lethal biological weapons can be produced through exactly the same techniques for manipulating living organisms that also allow the development of vaccines and medications. And it is not simply a question of distinguishing between potentially beneficial and potentially maleficent research. Reality is not as simple as that. Benefits and detriments often overlap in a complex way; benefits are immense and clear but detriments are sometimes even bigger, and unpredictable.

A very good example of this (and also epistemic authoritarianism, including clear cases of the suppression of scientific dissonance) is the "still hypothesis" of the Human Immunodeficiency Virus 
(HIV) originating from the initial research towards the development of an oral vaccine to stop polio ${ }^{52}$. After World War II, when polio was considered one of the worst public health problems, three great scientists became involved with research towards mass immunization: Jonas Salk, Albert Sabin and Hilary Koprowski. According to this "still hypothesis" ("still" because it has not yet been properly scrutinized), at least one type of Simian Immunodeficiency Virus was introduced in humans during the first mass vaccination campaigns which took place between 1957 and 1959 in Central Africa, giving rise to HIV-1.

This article does not aim to overvalue the extreme opposite of the current situation. Techno-scientists should be considered irreplaceable, since they possess the instrumental knowledge necessary so that the decision-making process is grounded in the most updated and precise information available, in the vanguard of techno-scientific knowledge, on the very border between what is known and what is unknown. Nonetheless, the debates in the philosophy of science that dealt particularly with scientific neutrality and the convergence on epistemic rationality offer significant arguments with which to contest these conceptions, calling into question the adequacy of techno-scientific knowledge to legitimize and justify decisions in the ambit of science and technology.

This article wishes, therefore, to take issue with the current modus operandi, which is characterized by a kind of collective paternalism because the techno-scientific community, without the direct involvement of wider society, promotes its own regulation. Once scientific neutrality and the convergence on epistemic rationality are contested, however, scientific autonomy should cease to be total, and instead of techno-scientific autoregulation there should be bioethics heteroregulation. Scientific paternalism should be replaced by a system of collective autonomy in which various actors participate in the management and influence the decision-making process.

Even if at some point in the future those arguments in the philosophy of science that have contested scientific neutrality and convergence on epistemic rationality come to be refuted, even if the scientists performing their research and development activities come to be considered neutral, objective and rational, techno-scientific paternalism would still not be acceptable. The reasons would be the same ones which, as a general rule, condemn paternalism in other contexts, such as the fact that the direct and indirect consequences of scientific undertakings are not restricted to the techno-scientific community but can in fact affect the whole of society.

Scientific endeavor has been a fantastic instrument for the advancement of human knowledge. And if we want science to remain so, it is imperative that it conducts a more vigorous dialogue with other forms of knowledge acquisition. The defenders of epistemic authoritarianism and scientism actually perform a disservice to the scientific and technological system itself. Debates in the philosophy of science have uncovered not only the limits of scientific endeavor that compromise the credibility of scientific and authoritarian views, but have also indicated a strategy that might make scientific and technological successes more frequent. Such a strategy would consist of abandoning the monopoly of convictions and instead cooperating closely with other forms of knowledge.

To say it as clearly as possible: there is no less scientific attitude than asserting that science is the only possible and imaginable way to explore the unknown and to reveal genuine knowledge. Science must be made more humane, in the sense of allowing subjectivity to influence with transparency and positivity the attempts of objective expressions. Epistemic values, instead of having a veiled role, must be considered with clarity.

And in this process of the humanization of science, the influence of science and technology development policies cannot be ignored. Government science and technology policies currently have a significant influence on scientific and technological development. Planning the allocation of financial resources - deciding which fields will receive bigger and longer-term investments, which will receive scarce and only short-term funding, and which will be overlooked entirely - is a fundamental stage in elaborating a list of goals, benefits to be enjoyed, and negative effects to be tolerated. From this arises the need to share with society the mandate, and equally the responsibilities, of designing science and technology development policies.

And there are no reasons to be afraid. In the management of countries' science and technology systems there is a world of riches to be gained from cooperation between the philosophy of science and bioethics, as well as from accepting the indispensability of investing in new research at the interface between these two fields. 
Article produced as part of postdoctoral research at the Program in Bioethics of the Universidade de Brasilia, Brazil. All the extracts originally produced in Portuguese were translated by the authors.

\section{Referências}

1. Popper KR. Conjecturas e refutações. Brasília: Editora Universidade de Brasília; 2008. p. 35-6.

2. Schramm FR. Bioética e biossegurança. In: Costa SIF, Oselka G, Garrafa V, coordenadores. Iniciação à bioética. Brasília: Conselho Federal de Medicina; 1998. p. 217-30, p. 217.

3. Schramm FR. Paradigma biotecnocientífico e paradigma bioético. In: Oda LM, organizadora. Biosafety of transgenic organisms in human health products. Rio de Janeiro: Fiocruz; 1996. p. 109-27, p. 114-5.

4. Popper KR. Lógica das ciências sociais. Rio de Janeiro: Tempo Brasileiro; 2004. p. 51.

5. Feyerabend PK. Knowledge, science and relativism. Philosophical papers vol 3. Cambridge: Cambridge University Press; 2008 p. 64-7.

6. Feyerabend PK. Op. cit. p. 55-6.

7. Feyerabend PK. Op. cit. p. 68-71.

8. Gómez AV. Toward a political philosophy of science. Philosophy Today. 2004; Suppl:78-83.

9. Popper KR. Realism and the aim of science. New York: Routledge; 2000. p. 8.

10. Popper KR. Em busca de um mundo melhor. São Paulo: Martins; 2006. p. 258.

11. Popper KR. Conjecturas e refutações. Brasília: Editora Universidade de Brasília; 2008. p. 391.

12. Popper KR. Op. cit.; 2006. p. 260.

13. Popper KR. Conhecimento objetivo. Belo Horizonte: Itatiaia; 1999. p. 144.

14. Popper KR. Op. cit.; 1999. p. 23.

15. Popper KR. The two fundamental problems of the theory of knowledge. New York: Routledge; 2009. p. 132.

16. Kuhn TS. Reflections on my critics. In: Lakatos I, Musgrave A. Criticism and the growth of knowledge. Cambridge: Cambridge University Press; 2004. p. 254.

17. Kuhn TS. O caminho desde a estrutura. São Paulo: Editora Unesp; 2003a. p. 51.

18. Kuhn TS. A estrutura das revoluções científicas. São Paulo: Perspectiva; 2007. p. 166.

19. Kuhn TS. Reflections on my critics. In: Lakatos I, Musgrave A. Criticism and the growth of knowledge. Cambridge: Cambridge University Press; 2004. p. 231-78, p. 262.

20. Kuhn TS. An analysis of causal connexity. Thomas S. Kuhn papers, 1922-1996. MC 240. Cambridge: Institute Archives and Special Collections, Massachusetts Institute of Technology; 1945. p. 14.

21. Lucas JVM. Intensions, belief and science: Kuhn's early philosophical outlook (1940-1945). Studies in History and Philosophy of Science. 2009; 40:175-84.

22. Kuhn TS. Op. cit; 2004. p. 264-5.

23. Kuhn TS. The Copernican revolution: planetary astronomy in the development of western thought. Cambridge: Harvard University Press; 2003b. p. 3.

24. Kuhn TS. Op. cit.; 2003b. p. 39.

25. Kuhn TS. Op. cit.; 2003b. p. 265.

26. Sankey H. Scientific realism and the semantic incommensurability thesis. Studies in History and Philosophy of Science. 2009; 40:196-202.

27. Kuhn TS. Op. cit.; 2003a. p. 138.

28. Kuhn TS. Op. cit.; 2003a. p. 139.

29. Sankey H. Kuhn's ontological relativism. Science and Education. 2000; 9:59-75.

30. Gunnell JG. Ideology and the philosophy of science: an American misunderstanding. Journal of Political Ideologies. 2009; 14(3):317-37.

31. Kuhn TS. The essential tension. Selected studies in scientific tradition and change. Chicago: The University of Chicago Press; 1977. p. 325.

32. Kuhn TS. Op. cit; 2007. p. 145.

33. Feyerabend PK. Farewell to reason. London: Verso; 2002. p. 23.

34. Feyerabend PK. Has the scientific view of the world a special status compared with other views? In: Feyerabend PK. Conquest of Abundance, A tale of abstraction versus the richness of being. Chicago: The Chicago University Press; 2001. p. 147-60, p. 152.

35. Feyerabend PK. Op. cit.; 2001. p. 152.

36. Feyerabend PK. Farewell to reason. London: Verso; 2002. p. 5.

37. Feyerabend PK. Op. cit.; 2002. p. 10.

38. Feyerabend PK. Contra o método. São Paulo: Editora Unesp; 2007. p. 87.

39. Sankey H. Scientific realism and the semantic incommensurability thesis. Studies in History and Philosophy of Science. 2009; 40:196-202.

40. Farrell RP. Feyerabend's metaphysics: process-realism, or voluntarist-idealism? Journal for General Philosophy of Science. 2001; 32:351-69.

41. Feyerabend PK. Contra o método. São Paulo: Editora Unesp; 2007. p. 283.

42. Feyerabend PK. Science in a free society. London: Verso; 1983. p. 192.

43. Feyerabend PK. Consolations for the specialist. In: Lakatos I, Musgrave A. Criticism and the growth of knowledge. Cambridge: Cambridge University Press; 2004. p. 197-230, p. 202. 
44. Feyerabend PK. Realism, rationalism and scientific method. Philosophical Papers vol 1. Cambridge: Cambridge University Press; 2003. p. 59.

45. Feyerabend PK. Op. cit.; 2002. p. 56.

46. Feyerabend PK. Diálogos sobre o conhecimento. São Paulo: Perspectiva; 2008. p. 90-1.

47. Feyerabend PK. Has the scientific view of the world a special status compared with other views? In: Feyerabend PK. Conquest of abundance, a tale of abstraction versus the richness of being. Chicago: The Chicago University Press; 2001. p. 147-60, p. 158.

48. Feyerabend PK. Science in a free society. London: Verso; 1983. p. 176-7.

49. Jonas H. Freedom of scientific inquiry and the public interest. The Hastings Center Report. 1976; 6(4):15-7, p. 16

50. Dahl RA. Sobre a democracia. Brasília: Editora Universidade de Brasília; 2009. p. 86.

51. Olivé L. Ética aplicada a las ciencias naturales y la tecnología. In: Ibarra A, Olivé L, editores. Cuestiones éticas en ciencia y tecnología en el siglo XXI. Madrid: Editorial Biblioteca Nueva; 2003. p. 181-223, p. 206, 207.

52. Martin B. Sticking a needle into science: the case of polio vaccines and the origin of AIDS. Social Studies of Science. 1996; 26:245-76.

\section{Participation of the authors}

Gabriele Cornelli oriented the first author, guiding the conception and design of the study. Márcio Rojas da Cruz undertook the analysis and prepared the article, which is part of his ongoing postdoctoral research.

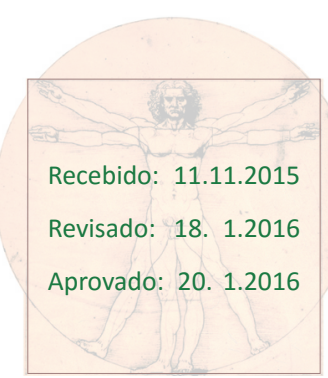

